\title{
IPTEKS ANALISIS HASIL LAPORAN KEUANGAN DAN ASET SULAWESI UTARA
}

\author{
Yosua Afryan Iriando Sipayung ${ }^{1}$, Hendrik Gamaliel $^{2}$ \\ ${ }^{1,2}$ Jurusan Akuntansi, Falkutas Ekonomi dan Bisnis, Universitas Sam Ratulangi, Jl. Kampus Bahu, Manado, \\ 95115, Indonesia \\ email; jojokelez@gmail.com
}

\begin{abstract}
Analysis of financial statements is a study that records financial statements of a company or government in a period and describes the results of performance on the company or government. Excess financial statements know information about financial conditions, financial capacity, and changes in company capital in the previous period. The low quality of financial statements can result in data inaccuracies that are in the company or government.. Financial statements are very important information in economic decision making. By analyzing financial statements, government accountants can determine the right in making a decision so that government goals can be achieved. In the implementation of decentralization and autonomy, regions are given the right to obtain financial resources, which include, in the form of certainty the availability of funding from the government in accordance with government affairs, authority to collect and use regional taxes and levies, the right to obtain proceeds from national resources being in the area and other balancing funds, the right to manage regional wealth and obtain other legitimate sources of income, as well as funding sources. The new paradigm changes in the management of State property / State assets which are marked by the issuance of Government Regulation No. 27 of 2014 which is a derivative regulation of Law No. 1 of 2004 concerning State Treasury, has given rise to new optimism in the arrangement and management of State assets that are more orderly, obligatory and transparent in the future. In the management of regional assets requires legal principles that can be a strong foundation in a regional asset management mechanism to avoid irregularities.
\end{abstract}

Keywords: Financial statements, regional assets, funds, regulations, obligations

\section{PENDAHULUAN}

Pemerintah sangat membutuhkan suatu instansi yang dapat mengatur dan menganalisis laporan keuangan pada suatu daerah. Namun Pemerintah bukan hanya mencari instansi yang dapat dapat mengatur dan menganaisis namun yang mempunyai skill-skill khusus dalam bidang mengatur dan menganalisis laporan keuangan. Selama ini Pemerintah memiliki hambatan di karenakan laporan keuangan tidak akurat dan tidak mempunyai orangorang yang mempunyai skill khusus dalam mengatur dan analisis laporan keuangan, dari kekurangan di dalam pemerintah tersebut banyaknya orang-orang yang kurang berkompeten dalam melakukan amanah yang di berikan. Contoh dari orang yang tidak bertanggung jawab ialah orang yang "Korupsi dan Suap". Analisis Laporan Keuangan adalah sebuah kaidah untuk membantu Pemerintah pada saat mengatur keuangan yang ada, sehingga keuangan pemerintah lebih akurat dalam pencatatan laporan keuangan.

\section{TINJAUAN PUSTAKA}

Akuntansi. Akuntansi merupakan pengukuran, penjabaran, atau memberikan kepastian mengenai informasi dan pengambilan keputusan untuk aktivitas keuangan. 
Laporan Keuangan. Laporan Keuangan merupakan catatan laporan dari suatu perusahaan atau pemerintah untuk mengetahui pendapatan atau laba pada periode yang berada di perusahaan atau pemerintah, dan gambaran tentang kualitas kinerja perusahaan atau pemerintah.

Aset. Aset adalah benda yang nantinya bisa di jualkan atau digunakan untuk perusahaan atau pemerintah. Sedangkan menurut Munawir aset adalah sarana atau sumber daya yang memiliki nilai ekonomis dan mampu menunjang perusahaan atau pemerintah untuk harga yang diperoleh atau nilai wajar yang diukur secara objektif.

\section{METODE DAN TEKNIK PENERAPAN IPTEKS}

\subsection{Metode Penerapan IPTEKS}

Metode ipteks yang diterapkan yaitu mengkaji proses laporan keuangan dan aset Sulawesi Utara berdasarkan PP Nomor 71 Tahun 2010.

\subsection{Teknik Penerapan IPTEKS}

Teknik ipteks yang diterapkan ialah melakukan uraian terhadap laporan keuangan pada peraturan PP 71/2010 berbasis akrual

\section{PEMBAHASAN}

\subsection{Gambaran Objek Penerapan Ipteks}

Kantor Gubernur Biro Organisasi Setda Prov. Sulut bergerak dalam aspek pembinaan dan pelatihan SDM merupakan sebuah keharusan bagi Unit Organisasi dalam memberikan apresiasi dan penegtahuan. Biro Organisasi mempunyai tujuan yaitu menciptakan sebuah organisasi yang mengakomodir urusan wajib dan pilihan yang menjadi hak Pemerintah Provinsi dan mempunyai keselarasan antara struktur dan beban kerja. Kantor Gubernur Biro Organisasi Setda Prov. Sulut teletak di Kota Manado, Kecamatan Wanea, Kelurahan Teling atas. Kantor Gubernur Biro Organisasi Setda Prov. Sulut terdiri dari 4 bidang yaitu Bagian Kelembagaan, Bagian Analisis Jabatan, Bagian Pengembangan Kinerja dan Bagian Ketatalaksanaan.

\subsection{Pembahasan}

Adanya Perincian keuangan yang dibuat untuk menyampaikan data yang akurat serta terperinci tentang keadaan finansial juga semua transaksi yang terjadi untuk perincian dalam 1 masa. Terlebih lagi berhubungan dengan pengaturan finansial negara, perincian finansial pemerintah teristimewa dipakai dalam mengimbangi manifestasi pemasukan, pengeluaran, pengiriman, dan pembiayaan menggunakan budget yang sudah diperhitungkan, dapat dinilai dari keadaan finansial, penilaian secara cepat dan tanggap dari suatu eksistensi perincian, dan menunjang dalam penentuan kaidah Undang-undang yang mengatur tersebut. Satuan Pengawasan Internal (SPI) merupakan sebuah sistem pengawasan internal pemerintah yang berkerjasama dengan jasa assurance dan consulting diharapkan untuk dapat memberikan perbaikan dan nilai tambah dalam proses penyelenggaraan pemerintahan dan membantu pemerintah mencapai tujuannya. Dalam melaksanakan peranan sebagai assurance dan consulting di ruang lingkup Satuan Pengawasan Internal (SPI) berhasil mengumpulkan informasi dan data hasil pengamatan yang berkaitan dengan kesimpulan pada keuangan negara pada perangkat kerja dan unit kerja di lingkungan pemerintah daerah di wilayah Prov. Sulut berisi tentang Laporan Hasil Pengawasan atas Kewajiban Keuangan Negara pada Prov. Sulut Tahun 2012. Laporan ini menyediakan sebagai hasil inspeksi SPI ada empat sudut pandang, yaitu: 1. kewajiban pelaporan keuangan, 2. kewajiban bendahara negara dan mengelola aset, 3. Kewajiban bagi pemerintah yang baik dan bersih, dan 4. kewajiban inspeksi atas pelaksanaan program lintas sectoral. 
Tabel 1. Siklus Laporan Keuangan :

\begin{tabular}{|c|c|c|c|}
\hline Pencatatan & $\rightarrow$ & Jurnal & \\
\hline Penggolongan & $\rightarrow$ & Buku Besar & \\
\hline Peringkasan & $\rightarrow$ & Neraca Saldo & \\
\hline & & & $\begin{array}{c}\rightarrow \text { Laporan Laba Rugi } \\
\rightarrow \text { Laporan Perubahan } \\
\text { Modal }\end{array}$ \\
\hline Pelaporan & $\rightarrow$ & Laporan Keuangan & $\begin{array}{c}\rightarrow \text { Neraca } \\
\rightarrow \text { Laporan Arus Kas } \\
\rightarrow \text { Catatan Atas Laporan } \\
\text { Keuangan }\end{array}$ \\
\hline
\end{tabular}

\section{KESIMPULAN DAN SARAN}

\subsection{Kesimpulan}

Laporan keuangan membuat pengamatan terkait hasil dalam laporan keuangan dan hasil dalam beberapa periode tersebut. Tujuan laporan keuangan adalah membandingkan hasil kerja dari pemerintah. Hasil final dari aktivitas akuntansi merupakan sebuah laporan keuangan yang dibuat oleh pemerintah atau pihak yang betanggung jawab atas laporan keuangan tersebut, sehingga perlu membuat analisis laporan keuangan dari suatu perusahaan atau pemerintah untuk medukung dan mengendalikan system pemerintah atau menyediakan gambaran situasi keuangan pada pihak yang berkompoten, seperti para pemegang saham, kreditur, dan pihak lainnya. Dengan adanya analisis laporan keuangan maka dapat melihat hasil kegiatan pemerintah dalam satu periode. Harta atau benda yakni kemampuan perdagangan dari suatu daerah. Kemampuan perdagangan berarti terdapat keuntungan pada bidang ekonomi yang juga dapat diperoleh pada periode yang akan datang, bisa menyokong kewajiban pemerintah daerah sebagai penyumbang jasa umum kepada masyarakat. Dalam sebuah daerah umumnya terdapat banyak aset yang dapat dikelola oleh Pemerintah. Namun cukup banyak dari aset itu yang belum maksimal penggunaannya, maka tujuan untuk meningkatkan PAD dalam membangunan daerah dalam prospek mendatang perlu adanya pengoptimalan pemanfaatannya. Di samping dapat meningkatkan lowongan pekerjaan dan mengurangi tingkat pengangguran, apalagi terhadap harta milik daerah yang saat ini masih belum digunakan.

\subsection{Saran}

Perlunya mengecek laporan keuangan terus menerus sehingga dapat meningkatkan kualitas laporan keuangan pemerintah, mengingat bahwa aset daerah tidak hanya dapat difungsikan oleh pihak internal Pemda saja namun juga dapat dimanfaatkan oleh pihak eksternal Pemda, sehingga pemanfaatan ini dapat memberikan dampak ekonomis bagi Pemda dan masyarakat setempat.

\section{DAFTAR PUSTAKA}

Akmal Hidayat. 2011. Pengaruh Economic Value Added, Market Share dan Earning Per Share Terhadap Return Saham (Studi Pada Perusahaan Manufaktur Jenis Consumer Goods di Bursa Efek Indonesia 2004-2007).

Dewi Hilda Gustrida, 2012, Analisis Hasil Audit BPK-RI atas Aset Tetap Pada Laporan Keuangan Kementerian/Lembaga, Tesis Magister Akuntansi Universitas Indonesia

Jurnal Wira Ekonomi Mikroskil (Volume 1, Nomor 01, April 2011, ISSN: 2088-9607).

Hanafi, Mahduh dan Abdul Halim, 2012, Analisis Laporan Keuangan. Yogyakarta: (UPP) STIM YKPN. 
Kasmir, 2014. Analisis Laporan Keuangan, Edisi Pertama, Cetakan Ketujuh. Jakarta: PT. Rajagrafindo Persada.

Keban, Yeremias T. (1995). Indikator Kinerja Pemda, Pendekatan Manajemen dan Kebijakan, Yogyakarta : Fisip UGM Republik Indonesia. 2004 UU No.1 Tahun 2004 Pasal 1 butir 11 tentang Perbendaharaan Negara.

Kema, Ihwan. 2013. Penyajian Laporan Keuangan Daerah Berdasarkan Standar Akuntansi Pemerintahan pada Pemerintah Kota Manado. Jurnal EMBA, 1(3), 664-781

Republik Indonesia. 2004 UU No. 32 tahun 2004 tentang Pemerintahan Daerah.

Republik Indonesia . 2004 UU No. 33 tahun 2004 tentang Perimbangan Keuangan Pusat dan Daerah.

Rorimpandey, Gaby wawancara. 2018. Wawancara Mengenai Proses Pembuatan Laporan Keuangan. J1. 17 Agustus no.69

Subra Maryam, k.r. dan Wild, Jhon j. 2011. Analisis Laporan Keuangan. Edisi 10. BPFE: Yogyakarta..

2007. Pernyataan Standard Akuntansi Keuangan. Salemba Empat: Jakarta. 